\title{
Holocene aeolian activities linked to Indian summer monsoon in the middle reaches of the Yarlung Zangbo River
}

LI Tuoyu ${ }^{1},{ }^{\text {ZZHANG Jifeng }}{ }^{2}$, WU Yongqiu ${ }^{3}$, DU Shisong ${ }^{3}$, MO Duowen ${ }^{4}$, LIAO Yinan ${ }^{4}$, CHEN Zhitong ${ }^{2}$, LIU Jianbao ${ }^{2}$, LI Qing ${ }^{5}$

1. Capital Normal University, Beijing 100048, China;

2. Key Laboratory of Alpine Ecology (LAE), Institute of Tibetan Plateau Research, CAS, Beijing 100101, China;

3. MOE Engineering Center of Desertification and Blown-sand Control, Beijing Normal University, Beijing 100875, China;

4. Laboratory for Earth Surface Processes, Ministry of Education, College of Urban and Environmental Sciences, Peking University, Beijing 100871, China;

5. Institute of Geographical Sciences, Hebei Engineering Research Center of Geographic Information Application, Hebei Academy of Sciences, Shijiazhuang 050011, China

\begin{abstract}
Widespread aeolian deposits on the Tibetan Plateau (TP) have provided valuable palaeoclimatic information. However, the primary factors (e.g., climate factors, human activity, and vegetation cover) controlling aeolian deposition remain elusive. In this paper, we use a dataset that comprises new and published ages of Holocene aeolian sand and loess in the middle reaches of the Yarlung Zangbo River to identify the primary controlling factors and palaeoclimatic implications of aeolian deposition. Several intervals of enhanced aeolian accumulation centered at 8.5-7.8, 6.4-5.8, 4.5-4.0, 3.1-1.8, and 0.9 ka are identified, generally consistent with regional low rainfall events and weak Indian summer monsoon (ISM). This suggests that regional wetness, dominated by the ISM, may play a key role in modulating dust emissions and aeolian deposition on centennial timescales. Our results show that on centennial- to millennial-scales, ISM activity can be reconstructed by non-continuous aeolian deposits in the monsoon dominated TP.
\end{abstract}

Keywords: Holocene; aeolian activity; dust; Indian summer monsoon; Tibetan Plateau

\section{Introduction}

The Tibetan Plateau (TP), with a mean elevation greater than $4000 \mathrm{~m}$ above sea level, plays a key role in modulating Asian and global climate systems (e.g., An et al., 2001; Molnar et

Received: $2020-03-20$ Accepted: $2020-10-15$

Foundation: National Natural Science Foundation of China, No.41601191, No.41871070, No.41877460; National Basic Research Program of China, No.2013CB956001; Special Researcher Project of Henan Province

Author: Li Tuoyu (1985-), Associate Professor, specialized in environmental archaeology and aeolian research.

E-mail: lituoyu@cnu.edu.cn

"Corresponding author: Zhang Jifeng (1986-), Assisstant Professor, specialized in paleoclimatology and paleolimnology. E-mail: zhangjifeng@itpcas.ac.cn 
al., 2010). Aeolian sediments are very widespread on the TP and have been used to reconstruct local and regional climatic and environmental changes (Lehmkuhl, 2000, 2014; Sun et al., 2007; Kaiser et al., 2009; Lai et al., 2009; Stauch et al., 2012, 2018; Stauch, 2015, 2016; Zhang et al., 2015; Feng et al., 2016; Dong et al., 2017). The TP contains aeolian sediments, which are mainly distributed on dry basins, wide river valleys, lakeshores, and other sites (Dong et al., 2017). These sediments always originate from local materials, including glacial outwash material (Sun et al., 2007; Zhang et al., 2015), fluvial/alluvial deposits, and exposed lake sediments from shrinking lakes (Lehmkuhl et al., 2000).

Although aeolian sand and loess deposits serve as an important archive for observing topographic and climatic events on the TP, the specific palaeoclimatic interpretations they reflect remain elusive. Generally, the formation of aeolian sediments requires three prerequisites: (1) availability of sediments for dust formation, (2) suitable wind for dust transportation, and (3) a suitable site for dust accumulation (Pye, 1995). Usually, the accumulation of aeolian sediments on the TP is interpreted as reflecting dry environments, while the formation of palaeosols is used as an indicator of wet climatic conditions (e.g., Lu et al., 2011; Chen et al., 2016). However, a number of recent studies have shown that the strongest aeolian accumulations occur during the relatively wet late Glacial and early Holocene, suggesting that suitable trapping conditions with sufficient vegetation cover may play a key role in the formation of aeolian sediments (Sun et al., 2007; Stauch, 2015; Qiang et al., 2016).

Local dust storms, sand dunes, and well-preserved aeolian sand and loess deposits are widespread in the southern TP (Li et al., 1999; Sun et al., 2007; Lai et al., 2009; Shen et al., 2012; Pan et al., 2014; Zhang et al., 2015; Li et al., 2016; Dong et al., 2017; Ling et al., 2019, 2020). Sun et al., (2007) dated loess deposits from several sites in the Yarlung Zangbo River (YZR) valley, southern TP, and found that aeolian deposits accumulated only after the last deglaciation and not during glacial periods. The authors suggested that the lack of glacial loess deposits was due to the minimal vegetation cover or the erosion of loess during deglaciation.

On the other hand, Lai et al. (2009) reported several ages of aeolian deposits from the Kyichu River valley, southern TP, throughout most of the last $100 \mathrm{ka}$, which is much older than what was previously thought. The authors worked with a dataset that comprises 24 ages of aeolian deposits and found episodic aeolian deposition at approximately 3, 8, 16-21, 33, and 79-83 ka, most of which can be explained through synchronous global arid events. Overall, a number of studies have reported late Quaternary aeolian deposits in the southern TP; however, only sporadic Holocene aeolian sediments have been reported, and their possible linkages to large-scale atmospheric circulations, such as the Indian summer monsoon (ISM) and the westerlies, remain unknown.

Previous studies have shown that the TP is predominantly controlled by the interplay between the ISM and the westerlies (Bohner, 2006; An et al., 2012; Zhu et al., 2015). Modern precipitation $\delta^{18} \mathrm{O}$ observations have shown that the ISM moisture can reach $34^{\circ}-35^{\circ} \mathrm{N}$ in the southern part of TP (e.g., Yao et al., 2013), while the northern part of the TP is primarily dominated by westerlies. In the middle reaches of the YZR, annual precipitation mainly occurs in summer under the influence of the ISM, while the effects of mid-latitude westerlies on regional precipitation are limited. Several palaeo-moisture records based on lake sediments in the region showed several regional wet and dry intervals associated with ISM va- 
variability during the Holocene (Zhu et al., 2002; Bird et al., 2014; Conroy et al., 2017). In this paper, we use a dataset that comprises six new and 46 prior published ages of Holocene aeolian sand and loess in the middle reaches of the YZR to identify aeolian dynamics on centennial to millennial timescales, and their association with large-scale atmospheric circulation (e.g., the ISM).

\section{Material and methods}

The YZR, with a length of 2,057 km, is the longest river in the southern TP; it lies between the Gangdise and Nyainqentanglha mountains and the Himalayas orogeny (Figure 1). In summer, the ISM intrudes through the YZR valley, delivering most of this region's annual precipitation, while in winter, the climate is cold and dry under the impact of mid-latitude westerlies (Zhang et al., 2017). Some reaches of the YZR are characterized by broad valleys that provided suitable sites for the formation of aeolian deposits, which were as large as $2736 \mathrm{~km}^{2}$ in 2008 (Shen et al., 2012). Optically stimulated luminescence (OSL), thermoluminescence $(\mathrm{TL})$, and radiocarbon $\left({ }^{14} \mathrm{C}\right)$ methods have been used to date aeolian sand and loess in the YZR basin and its surrounding areas (Sun et al., 2007; Li et al., 2010; Zhang et al., 2015; Li et al., 2016). Due to rapid bleaching by sunlight, luminescence methods are the most appropriate technique to date aeolian sediments (Singhvi et al., 2001; Wintle and Murray, 2006). Occasionally, the radiocarbon ages of plant residues, charcoal, and total organic matter in aeolian deposits are also used to measure the ages of dust depositions.

In this study, we sampled five aeolian profiles, named DRX, RM, WL, SK, and DPZ (Figures 1 and 2), in the YZR valley and obtained four OSL ages (Table 1) and two radiocarbon ages (Table 2). These aeolian profiles are located on the fluvial terraces or the foothills of mountains along the middle reaches of the YZR. Massive suspended sediments deposited in the braided river channels or alluvial fans are reworked by local near-surface winds in dry seasons, and they accumulate on the foothills of mountains along the river to form dunes and loess (Sun et al., 2007; Zhang et al., 2015). The DRX profile $\left(29^{\circ} 21^{\prime} 59.2^{\prime \prime} \mathrm{N}\right.$, $91^{\circ} 08^{\prime} 58.0^{\prime \prime} \mathrm{E}$ ) is located on a fluvial terrace and can be divided into four sedimentary units: 0-50 cm, fluvial sand; 50-60 cm, gravel unit; 60-90 cm, aeolian sand unit (an OSL age sample collected at $68-72 \mathrm{~cm}) ; 90-120 \mathrm{~cm}$, gravel unit. The RM profile $\left(29^{\circ} 21^{\prime} 10.0^{\prime \prime} \mathrm{N}\right.$, $88^{\circ} 27^{\prime} 41.5^{\prime \prime} \mathrm{E}$ ) is located on a foothill and can be divided into three sedimentary units: $0-65$ $\mathrm{cm}$, aeolian loess unit with plant roots (an OSL age sample collected at 28-32 cm); 65-130 $\mathrm{cm}$, palaeosol unit; 130-290 cm, aeolian loess unit (an OSL age sample collected at 208-212 $\mathrm{cm})$. The WL $\left(29^{\circ} 8^{\prime} 40.3^{\prime \prime} \mathrm{N}, 93^{\circ} 40^{\prime} 35.9^{\prime \prime}\right)$, SK $\left(29^{\circ} 17^{\prime} 58.1^{\prime \prime} \mathrm{N}, 91^{\circ} 24^{\prime} 41.3^{\prime \prime}\right)$, and DPZ $\left(29^{\circ} 17^{\prime} 0.4^{\prime \prime} \mathrm{N}, 91^{\circ} 38^{\prime} 54.7^{\prime \prime} \mathrm{E}\right)$ profiles are also located on foothills and consist mainly of aeolian sand with a thickness of approximately $440 \mathrm{~cm}$. A charcoal sample from the aeolian sand of SK and an organic matter sample from the aeolian sand of WL were used for ${ }^{14} \mathrm{C}$ dating of SK and WL, respectively (Table 2). An OSL sample was also collected from the aeolian sand of DPZ (Table 1).

Pure quartz was extracted in a dark room with a dimmed red light for OSL dating. Optically stimulated luminescence measurements were carried out on an automated Risø TL/OSL-DA-20-C/D reader, and $\mathrm{D}_{\mathrm{e}}$ values were calculated with the single aliquot regenerative-dose (SAR) protocol (Murray and Wintle 2000). Uranium $\left({ }^{238} \mathrm{U}\right)$, thorium $\left({ }^{232} \mathrm{Th}\right)$, and 
potassium $\left({ }^{40} \mathrm{~K}\right)$ concentrations were measured using inductively coupled plasma mass spectrometry (ICP-MS). The resulting dose rate for each sample was estimated based on depth, altitude, and geomagnetic latitude. Cosmic ray contributions were calculated based on Prescoott and Hutton (1994). The water content of each sample was set to $15 \% \pm 7 \%$. The measurement accuracy of the equivalent dose using the SAR protocol was approximately $2 \%$.The OSL samples were measured at the Nanjing Normal University and the Qinghai Normal University. The materials used for the two radiocarbon dating samples were charcoal and total organic matter, and the radiocarbon dating was processed at Peking University. IntCal13 was used to calibrate all radiocarbon data were calibrated for the calendar year (Reimer et al., 2013).

Table 1 OSL dating results of aeolian sediments in the YZR basin

\begin{tabular}{cccccccc}
\hline Sample & Depth (cm) & $\mathrm{U}(\mathrm{ppm})$ & $\mathrm{Th}(\mathrm{ppm})$ & $\mathrm{K}(\%)$ & $\begin{array}{c}\text { Dose rate } \\
\left(\mathrm{Gy} \cdot \mathrm{ka}^{-1}\right)\end{array}$ & De/Gy & $\begin{array}{c}\text { OSL age } \\
(\mathrm{ka})\end{array}$ \\
\hline DRX-OSL & $68-72$ & $1.56 \pm 0.3$ & $13.95 \pm 0.7$ & $2.41 \pm 0.04$ & $3.73 \pm 0.27$ & $2.93 \pm 0.30$ & $0.79 \pm 0.10$ \\
RM-OSL-1 & $28-32$ & $2.64 \pm 0.039$ & $17.8 \pm 0.025$ & $2.46 \pm 0.026$ & $4.36 \pm 0.32$ & $7.99 \pm 0.40$ & $1.83 \pm 0.29$ \\
RM-OSL-3 & $208-212$ & $3.09 \pm 0.038$ & $19.2 \pm 0.024$ & $2.06 \pm 0.030$ & $4.17 \pm 0.31$ & $19.35 \pm 0.98$ & $4.64 \pm 0.36$ \\
DPZ-OSL-3 & $436-440$ & $4.16 \pm 0.034$ & $18.2 \pm 0.025$ & $2.36 \pm 0.028$ & $4.76 \pm 0.35$ & $8.37 \pm 0.42$ & $1.76 \pm 0.18$ \\
\hline
\end{tabular}

Table 2 Radiocarbon dating results of aeolian sediments in the YZR basin

\begin{tabular}{ccccc}
\hline Sample & Depth/cm & Dating material & Conventional ${ }^{14} \mathrm{C}$ age $(\mathrm{BP}, 2 \sigma)$ & Calibrated ${ }^{14} \mathrm{C}$ age $(\mathrm{BP}, 2 \sigma)$ \\
\hline SK $-{ }^{14} \mathrm{C}-1$ & $435-439$ & Charcoal & $2880 \pm 25$ & $3005 \pm 37$ \\
$\mathrm{WL}-{ }^{14} \mathrm{C}-1$ & $50-55$ & Total organic matter & $710 \pm 20$ & $670 \pm 6$ \\
\hline
\end{tabular}

To show the regional patterns of aeolian activity, we also considered prior published ages of aeolian profiles in the middle reaches of the YZR. Ultimately, we obtained a dataset that comprises ages of aeolian sand and loess in the middle reaches of the YZR, including 52 ages from 28 profiles (Table 3 ). These profiles are mainly distributed in the broad valley of the YZR, with a small amount distributed in the YZR tributary valley (Figure 1). Cumulative probability density functions have been widely used for OSL age (e.g., Singhvi et al., 2001; Lai et al., 2009; Stauch, 2015) and radiocarbon age (e.g., Hoffmann et al., 2008) distribution analysis. Each OSL and radiocarbon age was assumed to be a dust deposition event, and respective probability density functions were calculated using the mean value and standard deviation of each age. Cumulative probability density functions were calculated at 50-year intervals: for each time point, with an interval of 50 years, we summed up the probability values of all the ages to obtain a cumulative probability distribution record. Peaks of the summed probability density distributions were thought to represent intervals of heavy dust deposition.

\section{Results and discussion}

The cumulative probability density curve of the ages of Holocene aeolian sediments in the middle reaches of the YZR, as shown in Figure 3a, shows the strongest deposition during the late Holocene and weak aeolian activity during the early Holocene. This contrasts with aeolian activity reports on the northeastern $\mathrm{TP}$, in which several recent studies have 


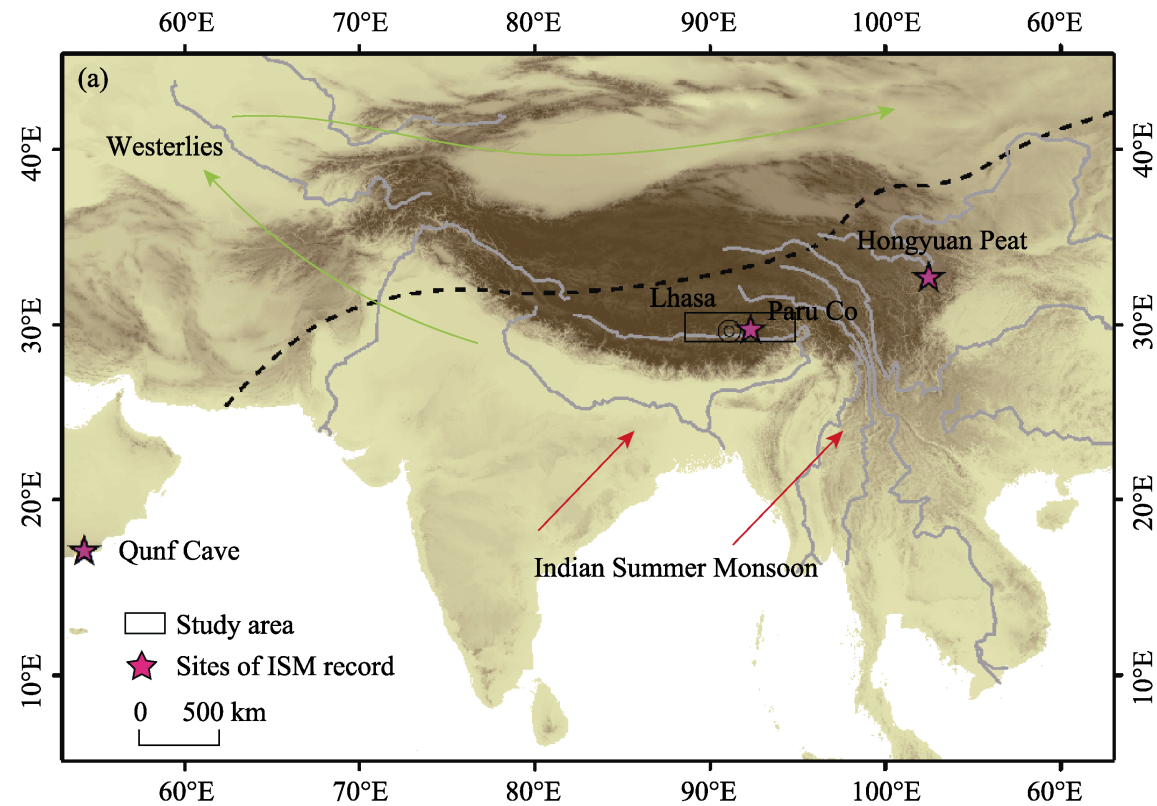

(b)

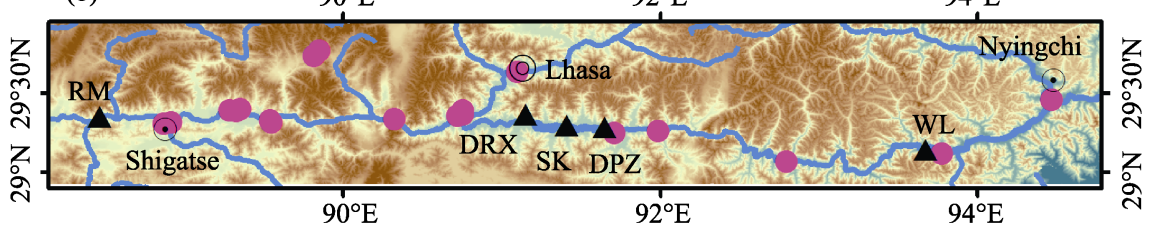

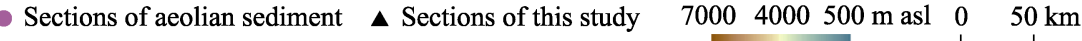

Figure 1 Location of the study area (a) and distribution of aeolian sediment profiles in the middle reaches of the YZR (b). The boundary of westerlies and the ISM (dashed line; Chen et al., 2010) are also shown.

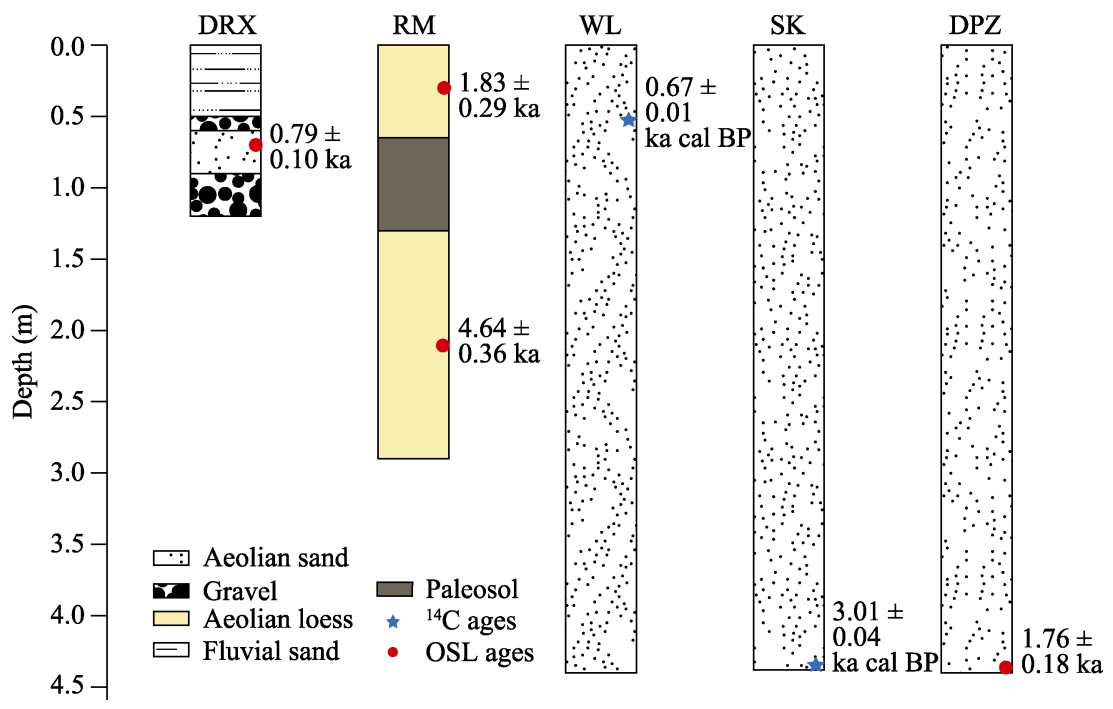

Figure 2 Sediment $\operatorname{logs}$ and ages of aeolian sand and loess in the middle reaches of the YZR 
Table 3 A dataset of synthesized ages of Holocene aeolian sediments in the middle reaches of the YZR

\begin{tabular}{|c|c|c|c|c|c|c|c|c|}
\hline Section & $\begin{array}{l}\text { Depth } \\
(\mathrm{cm})\end{array}$ & $\begin{array}{l}\text { Dating } \\
\text { method }\end{array}$ & Dating material & $\begin{array}{c}\text { Age }(\mathrm{ka} / \mathrm{cal} \\
\text { ka BP) }\end{array}$ & $\begin{array}{l}\text { Latitude } \\
\left({ }^{\circ} \mathrm{N}\right)\end{array}$ & $\begin{array}{c}\text { Longitude } \\
\left({ }^{\circ} \mathrm{E}\right)\end{array}$ & $\begin{array}{l}\text { Altitude } \\
\text { (m asl) }\end{array}$ & Source \\
\hline TB1 & 350 & OSL & Aeolian loess & $2.70 \pm 0.20$ & 29.3167 & 89.5500 & 3800 & Sun et al., 2007 \\
\hline TB7 & 380 & OSL & Aeolian loess & $11.00 \pm 1.20$ & 29.3167 & 88.9167 & 3920 & Sun et al., 2007 \\
\hline DAR1 & $300-325$ & ${ }^{14} \mathrm{C}$ & Charcoal & $3.15 \pm 0.08$ & - & - & - & Kaiser et al., 2009 \\
\hline STA1 & 50 & OSL & Aeolian sand & $2.90 \pm 0.20$ & 29.6331 & 91.0978 & 3660 & Kaiser et al., 2009 \\
\hline STA1 & 180 & OSL & Aeolian sand & $4.10 \pm 0.40$ & 29.6331 & 91.0978 & 3667 & Kaiser et al., 2009 \\
\hline STA1 & 280 & OSL & Aeolian sand & $6.70 \pm 0.50$ & 29.6331 & 91.0978 & 3667 & Kaiser et al., 2009 \\
\hline QUX 1 & 280 & OSL & Aeolian sand & $8.50 \pm 0.70$ & 29.3553 & 90.7234 & 3603 & Kaiser et al., 2009 \\
\hline QUX 2 & $325-330$ & ${ }^{14} \mathrm{C}$ & Charcoal & $7.78 \pm 0.07$ & 29.3659 & 90.7556 & 3536 & Kaiser et al., 2009 \\
\hline Section 48 & $67-73$ & OSL & Aeolian loess & $8.80 \pm 3.90$ & 29.7333 & 89.8167 & 4571 & Lehmkuhl et al., 2000 \\
\hline Section 49 & $47-53$ & OSL & Aeolian loess & $7.80 \pm 1.20$ & 29.7667 & 89.8500 & 4835 & Lehmkuhl et al., 2000 \\
\hline LXD & 170 & OSL & Aeolian loess & $7.90 \pm 0.90$ & 29.3275 & 89.5386 & 3797 & Hu et al., 2018 \\
\hline LXD & 98 & OSL & Aeolian loess & $3.20 \pm 0.30$ & 29.3275 & 89.5386 & 3797 & Hu et al., 2018 \\
\hline Xigaze & - & ${ }^{14} \mathrm{C}$ & Organic matter & $0.92 \pm 0.02$ & 29.3057 & 88.8688 & 3811 & Hu et al., 2018 \\
\hline TDD & 87 & OSL & Aeolian loess & $2.60 \pm 0.30$ & 29.3372 & 90.3236 & 3687 & Hu et al., 2018 \\
\hline TDD & 195 & OSL & Aeolian loess & $2.90 \pm 0.30$ & 29.3372 & 90.3236 & 3687 & Hu et al., 2018 \\
\hline TDD & 285 & OSL & Aeolian loess & $5.00 \pm 0.50$ & 29.3372 & 90.3236 & 3687 & Hu et al., 2018 \\
\hline JB & 260 & $\mathrm{TL}$ & Aeolian sand & $8.56 \pm 0.65$ & 29.3969 & 89.3500 & 3890 & Li et al., 2010 \\
\hline QS & 430 & $\mathrm{TL}$ & Aeolian loess & $8.85 \pm 0.53$ & 29.3900 & 90.7578 & 4000 & Li et al., 2010 \\
\hline GM & 340 & ${ }^{14} \mathrm{C}$ & Organic matter & $6.20 \pm 0.31$ & - & - & - & Li et al., 2010 \\
\hline GM & 531 & $\mathrm{TL}$ & Aeolian sand & $8.30 \pm 0.30$ & - & - & - & Li et al., 2010 \\
\hline Cha'er & 65 & ${ }^{14} \mathrm{C}$ & $\begin{array}{l}\text { Organic mat- } \\
\text { ter }^{\mathrm{a}}\end{array}$ & $2.23 \pm 0.10$ & 29.3895 & 89.2823 & 3856 & Zheng et al., 2009 \\
\hline Cha'er & 235 & $\mathrm{TL}$ & Aeolian sand & $8.56 \pm 0.65$ & 29.3895 & 89.2823 & 3856 & Zheng et al., 2009 \\
\hline ZD & 158 & OSL & Aeolian loess & $5.90 \pm 0.20$ & 29.2466 & 91.7120 & 3561 & Zheng, 2009 \\
\hline ZD & 628 & OSL & Aeolian sand & $8.50 \pm 0.60$ & 29.2466 & 91.7120 & 3561 & Zheng, 2009 \\
\hline CGG & 168 & OSL & Aeolian sand & $1.82 \pm 0.16$ & 29.3653 & 91.1491 & 3652 & Li et al., 2020 \\
\hline CGG & 287 & OSL & Aeolian sand & $8.43 \pm 0.66$ & 29.3653 & 91.1491 & 3652 & Li et al., 2020 \\
\hline YJP1 & 0.4 & OSL & Sandy loess & $1.90 \pm 0.10$ & 29.4556 & 94.4693 & 2943 & Ling et al., 2020 \\
\hline YJP1 & 0.9 & OSL & Sandy loess & $3.90 \pm 0.30$ & 29.4556 & 94.4693 & 2943 & Ling et al., 2020 \\
\hline YJP1 & 1.4 & OSL & Sandy loess & $4.40 \pm 0.30$ & 29.4556 & 94.4693 & 2943 & Ling et al., 2020 \\
\hline YJP1 & 1.9 & OSL & Sandy loess & $4.30 \pm 0.30$ & 29.4556 & 94.4693 & 2943 & Ling et al., 2020 \\
\hline YJP1 & 2.5 & OSL & Sandy loess & $5.10 \pm 0.40$ & 29.4556 & 94.4693 & 2943 & Ling et al., 2020 \\
\hline YJP1 & 3 & OSL & Sandy loess & $3.20 \pm 0.20$ & 29.4556 & 94.4693 & 2943 & Ling et al., 2020 \\
\hline YJP1 & 3.6 & OSL & Sandy loess & $8.30 \pm 0.60$ & 29.4556 & 94.4693 & 2943 & Ling et al., 2020 \\
\hline YJP2 & 1.7 & OSL & Sandy loess & $110 \pm 0.90$ & 29.4556 & 94.4693 & 2943 & Ling et al., 2020 \\
\hline MLP & 6.5 & OSL & Aeolian sand & $4.50 \pm 0.30$ & 29.1189 & 93.7781 & 3004 & Ling et al., 2020 \\
\hline MLP & 10 & OSL & Aeolian sand & $6.20 \pm 0.50$ & 29.1189 & 93.7781 & 3004 & Ling et al., 2020 \\
\hline LXP & 1.3 & OSL & Sandy loess & $4.90 \pm 0.40$ & 29.0668 & 92.7993 & 3172 & Ling et al., 2020 \\
\hline LXP & 2 & OSL & Sandy loess & $6.50 \pm 0.50$ & 29.0668 & 92.7993 & 3172 & Ling et al., 2020 \\
\hline SRP & 0.7 & OSL & Aeolian sand & $0.40 \pm 0.10$ & 29.2617 & 91.9873 & 3553 & Ling et al., 2020 \\
\hline
\end{tabular}


(Continued)

\begin{tabular}{ccccccccc}
\hline Section & $\begin{array}{c}\text { Depth } \\
(\mathrm{cm})\end{array}$ & $\begin{array}{c}\text { Dating } \\
\text { method }\end{array}$ & Dating material & $\begin{array}{c}\text { Age }(\mathrm{ka} / \mathrm{cal} \\
\mathrm{ka} \mathrm{BP})\end{array}$ & $\begin{array}{c}\text { Latitude } \\
\left({ }^{\circ} \mathrm{N}\right)\end{array}$ & $\begin{array}{c}\text { Longitude } \\
\left({ }^{\circ} \mathrm{E}\right)\end{array}$ & $\begin{array}{c}\text { Altitude } \\
(\mathrm{m} \text { asl })\end{array}$ & Source \\
\hline SRP & 1.4 & OSL & Aeolian sand & $0.80 \pm 0.10$ & 29.2617 & 91.9873 & 3553 & Ling et al., 2020 \\
SRP & 2.1 & OSL & Aeolian sand & $1.00 \pm 0.10$ & 29.2617 & 91.9873 & 3553 & Ling et al., 2020 \\
SRP & 2.8 & OSL & Aeolian sand & $1.10 \pm 0.10$ & 29.2617 & 91.9873 & 3553 & Ling et al., 2020 \\
SRP & 3.5 & OSL & Aeolian sand & $1.00 \pm 0.10$ & 29.2617 & 91.9873 & 3553 & Ling et al., 2020 \\
SRP & 4.2 & OSL & Aeolian sand & $1.20 \pm 0.10$ & 29.2617 & 91.9873 & 3553 & Ling et al., 2020 \\
SRP & 4.9 & OSL & Aeolian sand & $4.10 \pm 0.40$ & 29.2617 & 91.9873 & 3553 & Ling et al., 2020 \\
LCP & 2.9 & OSL & Sandy loess & $9.20 \pm 0.80$ & 29.3872 & 89.3254 & 3815 & Ling et al., 2020 \\
DRX & 70 & OSL & Aeolian sand & $0.79 \pm 0.10$ & 29.3664 & 91.1494 & 3656 & This study \\
RM & 30 & OSL & Aeolian loess & $1.83 \pm 0.29$ & 29.3528 & 88.4615 & 3876 & This study \\
RM & 210 & OSL & Aeolian loess & $4.64 \pm 0.36$ & 29.3528 & 88.4615 & 3876 & This study \\
WL & 52 & ${ }^{14} \mathrm{C}$ & Organic matter & $0.67 \pm 0.01$ & 29.1445 & 93.6766 & 3092 & This study \\
SK & 437 & ${ }^{14} \mathrm{C}$ & Charcoal & $3.01 \pm 0.04$ & 29.2995 & 91.4115 & 3557 & This study \\
DPZ & 438 & OSL & Aeolian sand & $1.76 \pm 0.18$ & 29.2835 & 91.6485 & 3584 & This study \\
\hline
\end{tabular}

reported increased dust accumulation during relatively wet late Glacial and early Holocene periods, highlighting the key role of vegetation cover as a dust trap in aeolian sediment accumulation (Stauch, 2015). Our synthesized curve is also punctuated by several strong dust deposition events (Figure 3a) centered at 8.5-7.8, 6.4-5.8, 4.5-4.0, 3.1-1.8, and 0.9 ka. Two of these events are similar to those reported in Lai et al. (2009) that analyzed a YZR tributary.

Several events of increased dust deposition in the middle reaches of the YZR, such as the event around $8 \mathrm{ka}$, have not been reported on the northeastern TP (e.g., Stauch, 2015), suggesting different mechanisms for aeolian sedimentation in the southern and northeastern TP. First, this difference can be related to the different atmospheric circulation backgrounds of the two regions. The northeastern TP is mainly influenced by the East Asian summer monsoon, while the southern TP is mainly impacted by the ISM. Second, this difference can be explained by the different mechanisms for the supply of dust to the two regions. The much larger area of desertic land on the northeastern TP may provide sufficient supplies of dust during the early Holocene. Thus, improved vegetation cover, as a sediment trap, may contribute to an enhanced aeolian deposition during the early Holocene. In contrast, aeolian sediments in the YZR valley are supplied by local dust, which is mainly generated from small areas of outwash sediment and desertic land in the low-level floodplains (Sun et al., 2007; Zhang et al., 2015). Strong ISM activity in response to high summer insolation (Figure 3b) and increased regional monsoon rainfall during the early Holocene (Fleitmann et al., 2003; Gupta et al., 2003) may improve vegetation cover in the source area and significantly inhibit dust supply and aeolian activity in the middle reaches of the YZR. Finally, the confined valley landscape of the YZR, which differs significantly from the open terrain in northern TP, may partly explain the differences in aeolian activity between the two regions. 


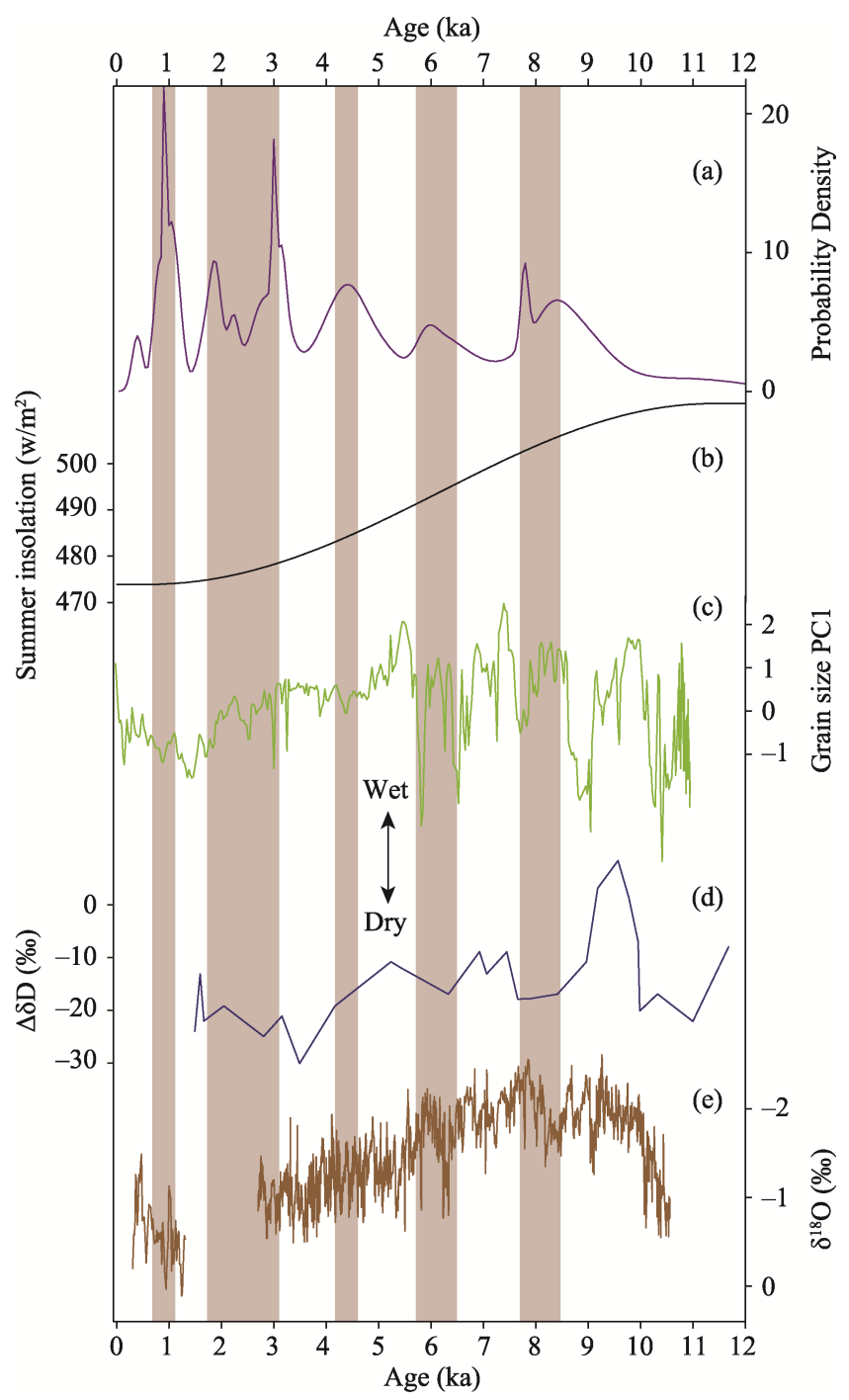

Figure 3 Comparison of the probability density curve for Holocene aeolian sediment ages in the middle reaches of the YZR (a) with other palaeoclimatic records: (b) summer insolation at $30^{\circ} \mathrm{N}$ (Berger and Loutre, 1991); (c) a lake-level record reconstructed by the PC1 grain size of the Lake Paru Co (Bird et al., 2014); (d) isotopic divergence between $\mathrm{C}_{23}$ and $\mathrm{C}_{31}$ n-alkanes $(\Delta \delta \mathrm{D})$ in Hongyuan peat (Seki et al., 2011); (e) a stalagmite $\delta^{18} \mathrm{O}$ record from southern Oman (Fleitmann et al., 2003).

To gain a better understanding of the controlling factors of aeolian sedimentation in the middle reaches of the YZR, we compared our records with regional palaeoclimatic records. Reconstructed aeolian activities identified in this study are generally consistent with regional palaeohydrological records on the TP. Monsoon rainfall record collected from Paru Co, which is located in the southern TP, shows that several intervals of increased dust deposition mostly happen in the dry seasons (Bird et al., 2014) (Figure 3c). In this study, the strong aeolian sediment accumulation events approximately $8.5-7.8,6.4-5.8$, and 3.1-1.8 $\mathrm{ka}$ are consistent with several dry season intervals identified by a rainfall record based on leaf wax hydrogen isotopic evidence from Hongyuan peat (Seki et al., 2011) (Figure 3d). A pollen record from Lake Tangra Yumco, in central TP, has identified several weak ISM events at 
8.2-7.4, 5.5, 4.7-3.7, and 3.2 ka (Ma et al., 2019), which are largely consistent with several dust deposition events identified in this study, given the dating uncertainty of the different archives. Moreover, the drought event around 8.5-7.8 ka is also found in other lacustrine records in the western (Gasse et al., 1996; Hou et al., 2017), central (Zhu et al., 2008; Doberschutz et al., 2014; Ma et al., 2014), and eastern (Hong et al., 2003; Kramer et al., 2010) TP. Our research has made it possible to record a long duration of increased dust deposition at 3.1-1.8 ka, which is consistent with the expected significantly reduced monsoon rainfall events across the TP (Zhu et al., 2008; Liu et al., 2009; Xie et al., 2009; Kramer et al., 2010; Zhao et al., 2011; Hou et al., 2017; Shi et al., 2017).

Modern precipitation isotope observations have shown that moistures transported by the ISM can invade the TP through the Brahmaputra/YZR valley and reach as far as the Tanggula Mountains (Tian et al., 2001, 2007). To identify the main climatic controlling factors for dust deposition in the southern TP, we compared our results with several records of ISM activity in Asia that have been reconstructed by marine sediment and stalagmite. Our reconstructed aeolian activity intensity in the YZR basin is perfectly consistent with the ISM variability reconstructed by a stalagmite $\delta^{18} \mathrm{O}$ record from the Qunf Cave in southern Oman (Fleitmann et al., 2003) (Figure 3e) and a G. bulloides percentage record from the Arabian Sea (Gupta et al., 2003). Several intervals of strong aeolian accumulation found in this study, subject to dating error, coincide with pauses of weak summer monsoons despite the two weak monsoon events during the early Holocene. The strongest dust sedimentation at 3.1-1.8 ka is associated with a period of hiatus of stalagmite growth in the Qunf Cave (Fleitmann et al., 2003) and a period with the most positive $\delta^{18} \mathrm{O}$ values in the Dongge Cave (Wang et al., 2005), suggesting that severe drought may have caused this long-lasting increased dust deposition. Generally, the similarity of our results with above ISM records suggests that the regional rainfall in the southern TP, controlled by ISM circulations, may play a key role in regulating regional aeolian activity during the Holocene. Several previous studies have also found a strong correlation between aeolian activity on the TP and summer monsoon intensity (Thompson et al., 2000, Qiang et al., 2014). An ice core record from Dasuopu, in the Himalayas (Thompson et al., 2000), showed that dust storm frequency has increased over the last 200 years, consistent with reduced ISM rainfall (Chu et al., 2011). In general, weaker summer monsoon winds and reduced summer rainfall can prolong wind erosion periods and also lead to degraded vegetation cover, which can facilitate aeolian erosion and dust accumulation.

Different views exist on the main factors that control aeolian deposition on the TP. The formation of aeolian sediments requires/depends on the availability of dust sources, wind transportation, and suitable environment for dust deposition (Pye, 1995). Previous studies on the northeastern TP ( $\mathrm{Lu}$ et al., 2011; Chen et al., 2016) have interpreted the accumulation of aeolian sand and loess as an indicator of a relatively dry environment that ensures an adequate dust supply. However, Stauch (2015) found that increased accumulation of dust occurred during the late Glacial and early Holocene across the TP, suggesting that vegetation cover, as a dust trap, may play a key role in the formation of these deposits. Sun et al. (2007), based on OSL ages of aeolian loess in the YZR valley, found that in the southern TP loess deposits had a basal age of 13-11 ka and concluded that the absence of full glacial loess is mainly due to minimal vegetation cover. In contrast, Lai et al. (2009) found older aeolian 
deposits in a YZR tributary and defined several intervals of increased sediment accumulation at approximately $16-21,33$, and $79-83 \mathrm{ka}$. The two aeolian sediment accumulation events at approximately 3 and $8 \mathrm{ka}$, which are identified in this study, have been explained to be associated with two drought events in response to consistent global climate changes. Based on a relatively larger dataset, we find five intervals of increased aeolian sediment accumulation in the middle reaches of the YZR during the Holocene, which tend to be associated with weak ISM events. The coincidence of dust deposition events with dry periods suggests that the predominant driver of aeolian sedimentation may be the climatic controlled dust emission, rather than vegetation cover. Recently, several studies have found footprints of permanent human occupation in central (Meyer et al., 2017; Zhang et al., 2018) and the northeastern (Chen et al., 2015, 2019) TP during the Holocene and earlier periods. As a result, the probable impact of human activity on aeolian activity during the Holocene cannot be ruled out. Due to a dearth of information on the extent of human activity in ancient southern TP, it is difficult to ascertain the extent to which human activity may have affected Holocene aeolian sand accumulations.

\section{Conclusions}

In this paper, we constructed a probability density curve of the ages of aeolian sand and loess in the middle reaches of the YZR, reflecting regional aeolian sediment accumulation intensity. We achieved this using a dataset that comprises new and prior published ages of Holocene aeolian sand and loess. In contrast to related studies on the northeastern TP, we found weak aeolian activities during the early Holocene in this region, and this may be associated with intensified ISM rainfall as a result of high summer insolation. Our results showed several intervals of increased dust accumulation centered at 8.5-7.8, 6.4-5.8, $4.5-4.0,3.1-1.8$, and $0.9 \mathrm{ka}$. These events are consistent with regional low rainfall events and weak ISM events. Regional monsoon rainfall/wetness, dominated by ISM activity, may play a key role in modulating dust emissions and aeolian deposition in the middle reaches of the YZR at centennial timescales. Overall, this study shows that aeolian deposits in the monsoon dominated TP can provide valuable information on past ISM activities. In the future, more effects of ISM activity would be identified with the availability of more data on the ages of aeolian sediments.

\section{References}

An Z, Colman S M, Zhou W et al., 2012. Interplay between the Westerlies and Asian monsoon recorded in Lake Qinghai sediments since 32 ka. Scientific Reports, 2: 619.

An Z, Kutzbach J E, Prell W L et al., 2001. Evolution of Asian monsoons and phased uplift of the Himalaya-Tibetan Plateau since Late Miocene times. Nature, 411(6833): 62-66.

Berger A, Loutre M F, 1991. Insolation values for the climate of the last 10 million years. Quaternary Science Reviews, 10(4): 297-317.

Bird B W, Polisar P J, Lei Y et al., 2014. A Tibetan lake sediment record of Holocene Indian summer monsoon variability. Earth and Planetary Science Letters, 399: 92-102.

Böhner J, 2006. General climatic controls and topoclimatic variations in Central and High Asia. Boreas, 35(2): 279-295.

Chen F, Welker F, Shen C et al., 2019. A late Middle Pleistocene Denisovan mandible from the Tibetan Plateau. 
Nature, 569(7756): 409-412.

Chen F, Wu D, Chen J et al., 2016. Holocene moisture and East Asian summer monsoon evolution in the northeastern Tibetan Plateau recorded by Lake Qinghai and its environs: A review of conflicting proxies. Quaternary Science Reviews, 154: 111-129.

Chen F H, Dong G H, Zhang D J et al., 2015. Agriculture facilitated permanent human occupation of the Tibetan Plateau after 3600 B.P. Science, 347(6219): 248-250.

Chu G, Sun Q, Yang K et al., 2011. Evidence for decreasing South Asian summer monsoon in the past 160 years from varved sediment in Lake Xinluhai, Tibetan Plateau. Journal of Geophysical Research, 116 (D02116): $1-11$.

Chen F, Chen J, Holmes J A et al., 2010. Moisture changes over the last millennium in arid Central Asia: A review, synthesis and comparison with monsoon region. Quaternary Science Reviews, 29(7): 1055-1068.

Conroy J L, Hudson A M, Overpeck J T et al., 2017. The primacy of multidecadal to centennial variability over late-Holocene forced change of the Asian monsoon on the southern Tibetan Plateau. Earth and Planetary Science Letters, 458: 337-348.

Doberschütz S, Frenzel P, Haberzettl T et al., 2014. Monsoonal forcing of Holocene paleoenvironmental change on the central Tibetan Plateau inferred using a sediment record from Lake Nam Co (Xizang, China). Journal of Paleolimnology, 51(2): 253-266.

Dong Z, Hu G, Qian G et al., 2017. High-altitude aeolian research on the Tibetan Plateau. Reviews of Geophysics, 55(4): 864-901.

Feng J L, Hu H P, Chen F, 2016. An eolian deposit-buried soil sequence in an alpine soil on the northern Tibetan Plateau: Implications for climate change and carbon sequestration. Geoderma, 266: 14-24.

Fleitmann D, Burns S J, Mudelsee M et al., 2003. Holocene forcing of the Indian monsoon recorded in a stalagmite from southern Oman. Science, 300(5626): 1737-1739.

Gasse F, Fontes J C, Van Campo E et al., 1996. Holocene environmental changes in Bangong Co basin (Western Tibet). Part 4: Discussion and conclusions. Palaeogeography, Palaeoclimatology, Palaeoecology, 120(1/2): 79-92.

Gupta A K, Anderson D M, Overpeck J T, 2003. Abrupt changes in the Asian southwest monsoon during the Holocene and their links to the North Atlantic Ocean. Nature, 421(6921): 354-357.

Hoffmann T, Lang A, Dikau R, 2008. Holocene river activity: Analysing ${ }^{14} \mathrm{C}$-dated fluvial and colluvial sediments from Germany. Quaternary Science Reviews, 27(21): 2031-2040.

Hong Y, Hong B, Lin Q H et al., 2003. Correlation between Indian Ocean summer monsoon and North Atlantic climate during the Holocene. Earth and Planetary Science Letters, 211(3/4): 371-380.

Hou J, D'Andrea W J, Wang M et al., 2017. Influence of the Indian monsoon and the subtropical jet on climate change on the Tibetan Plateau since the late Pleistocene. Quaternary Science Reviews, 163: 84-94.

$\mathrm{Hu}$ H, Feng J, Chen F, 2018. Sedimentary records of a palaeo-lake in the middle Yarlung Tsangpo: Implications for terrace genesis and outburst flooding. Quaternary Science Reviews, 192: 135-148.

Hudson A M, Olsen J W, Quade J, 2014. Radiocarbon dating of interdune paleo-wetland deposits to constrain the age of Mid-to-Late Holocene microlithic artifacts from the Zhongba site, southwestern Qinghai-Tibet Plateau. Geoarchaeology, 29(1): 33-46.

Kaiser K, Lai Z, Schneider B et al., 2009. Stratigraphy and palaeoenvironmental implications of Pleistocene and Holocene aeolian sediments in the Lhasa area, southern Tibet (China). Palaeogeography, Palaeoclimatology, Palaeoecology, 271(3/4): 329-342.

Kramer A, Herzschuh U, Mischke S et al., 2010. Holocene treeline shifts and monsoon variability in the Hengduan Mountains (southeastern Tibetan Plateau), implications from palynological investigations. Palaeogeography, Palaeoclimatology, Palaeoecology, 286(1): 23-41.

Lai Z, Kaiser K, Brückner H, 2009. Luminescence-dated aeolian deposits of late Quaternary age in the southern Tibetan Plateau and their implications for landscape history. Quaternary Research, 72(3): 421-430.

Lehmkuhl F, Klinge M, Rees-Jones J et al., 2000. Late Quaternary aeolian sedimentation in central and south-eastern Tibet. Quaternary International, 68-71: 117-132. 
Lehmkuhl F, Schulte P, Zhao H et al., 2014. Timing and spatial distribution of loess and loess-like sediments in the mountain areas of the northeastern Tibetan Plateau. Catena, 117: 23-33.

Li S, Dong G, Shen J et al., 1999. Formation mechanism and development pattern of aeolian sand landform in Yarlung Zangbo River valley. Science in China Series D: Earth Sciences, 42(3): 272-284.

Li S, Yang P, Dong Y et al., 2010. Desertification and Its Control in Tibet. Beijing: Science Press. (in Chinese)

Li T, Ren X, Liao Y et al., 2020. Paleoenvironment analysis of the middle reaches of Yarlung Zangbo River and Changguogou site. Quaternary Sciences, 40(2): 547-555. (in Chinese)

Li T, Wu Y, Du S et al., 2016. Geochemical characterization of a Holocene aeolian profile in the Zhongba area (southern Tibet, China) and its paleoclimatic implications. Aeolian Research, 20: 169-175.

Ling Z, Jin J, Wu D et al., 2019. Aeolian sediments and their paleoenvironmental implication in the Yarlung Zangbo catchment (southern Tibet, China) since MIS3. Acta Geographica Sinica, 74(11): 2385-2400. (in Chinese)

Ling Z, Yang S, Wang X et al., 2020. Spatial-temporal differentiation of eolian sediments in the Yarlung Tsangpo catchment, Tibetan Plateau, and response to global climate change since the Last Glaciation. Geomorphology, 357: 107104.

Liu X, Dong H, Yang X et al., 2009. Late Holocene forcing of the Asian winter and summer monsoon as evidenced by proxy records from the northern Qinghai-Tibetan Plateau. Earth and Planetary Science Letters, 280(1): 276-284.

Lu H, Zhao C, Mason J et al., 2011. Holocene climatic changes revealed by aeolian deposits from the Qinghai Lake area (northeastern Qinghai-Tibetan Plateau) and possible forcing mechanisms. Holocene, 21(2): 297-304.

Ma Q, Zhu L, Lü X et al., 2014. Pollen-inferred Holocene vegetation and climate histories in Taro Co, southwestern Tibetan Plateau. Chinese Science Bulletin, 59(31): 4101-4114.

Ma Q, Zhu L, Lü X et al., 2019. Late glacial and Holocene vegetation and climate variations at Lake Tangra Yumco, central Tibetan Plateau. Global and Planetary Change, 174: 16-25.

Meyer M C, Aldenderfer M, Wang Z et al., 2017. Permanent human occupation of the central Tibetan Plateau in the early Holocene. Science, 355(6320): 64-67.

Molnar P, Boos W R, Battisti D S, 2010. Orographic controls on climate and paleoclimate of Asia: Thermal and mechanical roles for the Tibetan Plateau. Annual Review of Earth and Planetary Sciences, 38(1): 77-102.

Murray A S, Wintle A G, 2000. Application of the single-aliquot regenerative-dose protocol to the $375^{\circ} \mathrm{C}$ quartz TL signal. Radiation Measurements, 32(5): 579-583.

Pan M, Wu Y, Zheng Y et al., 2014. Holocene aeolian activity in the Dinggye area (southern Tibet, China). Aeolian Research, 12: 19-27.

Prescott J R, Hutton J T, 1994. Cosmic ray contribution to dose rates for luminescence and ESR dating: Large depths and long-term time variations. Radiation Measurements, 23(2/3): 497-500.

Pye K, 1995. The nature, origin and accumulation of loess. Quaternary Science Reviews, 14(7/8): 653-667.

Qiang M, Jin Y, Liu X et al., 2016. Late Pleistocene and Holocene aeolian sedimentation in Gonghe Basin, northeastern Qinghai-Tibetan Plateau: Variability, processes, and climatic implications. Quaternary Science Reviews, 132: 57-73.

Qiang M, Liu Y, Jin Y et al., 2014. Holocene record of eolian activity from Genggahai Lake, northeastern Qinghai-Tibetan Plateau, China. Geophysical Research Letters, 41(2): 589-595.

Reimer P J, Bard E, Bayliss A et al., 2013. IntCal13 and Marine13 radiocarbon age calibration curves 0-50,000 years cal BP. Radiocarbon, 55(4): 1869-1887.

Seki O, Meyers P A, Yamamoto S et al., 2011. Plant-wax hydrogen isotopic evidence for postglacial variations in delivery of precipitation in the monsoon domain of China. Geology, 39(9): 875-878.

Shen W, Li H, Sun M et al., 2012. Dynamics of aeolian sandy land in the Yarlung Zangbo River basin of Tibet, China from 1975 to 2008. Global and Planetary Change, 86/87: 37-44.

Shi X, Kirby E, Furlong K P et al., 2017. Rapid and punctuated Late Holocene recession of Siling Co, central Tibet. Quaternary Science Reviews, 172: 15-31. 
Singhvi A, Bluszcz A, Bateman M et al., 2001. Luminescence dating of loess-palaeosol sequences and coversands: Methodological aspects and palaeoclimatic implications. Earth-Science Reviews, 54(1-3): 193-211.

Stauch G, 2015. Geomorphological and palaeoclimate dynamics recorded by the formation of aeolian archives on the Tibetan Plateau. Earth-Science Reviews, 150: 393-408.

Stauch G, 2016. Multi-decadal periods of enhanced aeolian activity on the north-eastern Tibet Plateau during the last 2 ka. Quaternary Science Reviews, 149: 91-101.

Stauch G, Ijmker J, Pötsch S et al., 2012. Aeolian sediments on the north-eastern Tibetan Plateau. Quaternary Science Reviews, 57: 71-84.

Stauch G, Lai Z, Lehmkuhl F et al., 2018. Environmental changes during the late Pleistocene and the Holocene in the Gonghe Basin, north-eastern Tibetan Plateau. Palaeogeography, Palaeoclimatology, Palaeoecology, 509: 144-155.

Sun J, Li S, Muhs D R et al., 2007. Loess sedimentation in Tibet: Provenance, processes, and link with Quaternary glaciations. Quaternary Science Reviews, 26(17/18): 2265-2280.

Thompson L G, Yao T, Mosleythompson E et al., 2000. A high-resolution millennial record of the South Asian monsoon from Himalayan ice cores. Science, 289(5486): 1916-1919.

Tian L, Yao T, MacClune K et al., 2007. Stable isotopic variations in west China: A consideration of moisture sources. Journal of Geophysical Research: Atmospheres, 112(D10112): 1-12.

Tian L D, Masson-Delmotte V, Stievenard M et al., 2001. Tibetan Plateau summer monsoon northward extent revealed by measurements of water stable isotopes. Journal of Geophysical Research Atmospheres, 106(D22): 28081-28088

Wang Y, Cheng H, Edwards R L et al., 2005. The Holocene Asian monsoon: Links to solar changes and North Atlantic climate. Science, 308(5723): 854-857.

Wintle A G, Murray A S, 2006. A review of quartz optically stimulated luminescence characteristics and their relevance in single-aliquot regeneration dating protocols. Radiation Measurements, 41(4): 369-391.

Xie M, Zhu L, Peng P et al., 2009. Ostracod assemblages and their environmental significance from the lake core of the Nam Co on the Tibetan Plateau 8.4 kaBP. Journal of Geographical Sciences, 19(4): 387-402.

Yao T, Masson-Delmotte V, Gao J et al., 2013. A review of climatic controls on $\delta^{18} \mathrm{O}$ in precipitation over the Tibetan Plateau: Observations and simulations. Reviews of Geophysics, 51(4): 525-548.

Zhang J, Feng J L, Hu G et al., 2015. Holocene proglacial loess in the Ranwu valley, southeastern Tibet, and its paleoclimatic implications. Quaternary International, 372: 9-22.

Zhang J F, Xu B, Turner F et al., 2017. Long-term glacier melt fluctuations over the past 2500 yr in monsoonal High Asia revealed by radiocarbon-dated lacustrine pollen concentrates. Geology, 45(4): 359-362.

Zhang X, Ha B B, Wang S et al., 2018. The earliest human occupation of the high-altitude Tibetan Plateau 40 thousand to 30 thousand years ago. Science, 362(6418): 1049-1051.

Zhao Y, Yu Z, Zhao W, 2011. Holocene vegetation and climate histories in the eastern Tibetan Plateau: Controls by insolation-driven temperature or monsoon-derived precipitation changes? Quaternary Science Reviews, 30(9): 1173-1184.

Zheng Y, 2009. The response of Holocene aeolian activities to climate change in the typical area of Qinghai-Tibet Plateau: Take the broad valley area in the middle reaches of the Yarlung Zangbo River in south Tibet and the Gonghe basin in Qinghai as examples [D]. Beijing: Beijing Capital Normal University. (in Chinese)

Zheng Y, Wu Y, Li S et al., 2009. Grain-size characteristics of sediments formed since 8600 yr BP in middle reaches of Yarlung Zangbo River in Tibet and their paleoenvironmental significance. Chinese Geographical Science, 19(2): 113-119.

Zhu L, Li Y, Li B et al., 2002. The ostracod assemblages and their environmental significance in the Chen Co area, southern Tibet in recent 1400 years. Journal of Geographical Sciences, 12(4): 451-459.

Zhu L, Lü X, Wang J et al., 2015. Climate change on the Tibetan Plateau in response to shifting atmospheric circulation since the LGM. Scientific Reports, 5: 13318.

Zhu L, Wu Y, Wang J et al., 2008. Environmental changes since 8.4 ka reflected in the lacustrine core sediments from Nam Co, central Tibetan Plateau, China. The Holocene, 18(5): 831-839. 